Original Research Paper

\title{
Effect of Various Combustible Materials on Insulating Properties of Refractory Bricks
}

\author{
${ }^{1}$ Isiaka Olajide Odewale ${ }^{*}{ }^{2}$ Ebere Monica Ameh, ${ }^{1}$ Victor Tyonenge Dhave Amaakaven, ${ }^{1}$ Felix Uga Idu, \\ ${ }^{4}$ Collins Chinecherem Aluma, ${ }^{5}$ Babatunde Joseph David, ${ }^{1}$ Oluwakayode. Boluwaji. Abe and ${ }^{3}$ Dele Kehinde \\ Ogunkunle
}

${ }^{1}$ Department of Ceramic and Glass Technology, Akanu Ibiam Federal Polytechnic Unwana, Afikpo, Ebonyi State, Nigeria ${ }^{2}$ Department of Metallurgical and Materials Engineering, Enugu State University of Science and Technology Enugu, Enugu State, Nigeria

${ }^{3}$ Department of Mechanical Engineering, Federal Polytechnic Nekede, Owerri, Imo State, Nigeria

${ }^{4}$ Development of National Space Research and Agency, Ile-Ife, Nigeria

${ }^{5}$ Department of Geology, Achievers University Owo, Ondo state, Nigeria

Article history

Received: 30-04-2020

Revised: 19-06-2020

Accepted: 21-07-2020

Corresponding author: Isiaka Olajide Odewale Department of Ceramic and Glass Technology, Akanu Ibiam Federal Polytechnic Unwana, Afikpo, Ebonyi State, Nigeria

Email: easyceramicglass@gmail.com
Abstract: The effect of various combustible materials on insulating properties of refractory bricks produced from Enugu fire clay and Ekebedi clay has been studied. This is aimed at determining the most favourable combustible material for different composition(s). The clays with combustible materials were used to compose different samples labeled A-G with varying percentages of combustible materials at reducing rate of 5\% from 40 to $10 \%$. The combustible materials used were paper pulp, saw dust, rice husk and cow dung. Properly mixed bodies with required moisture content were hydraulically pressed into shape and the bricks were oven-dried at temperature of $\pm 110^{\circ} \mathrm{C}$. The properties of the produced insulating bricks were investigated after sintering at $1300^{\circ} \mathrm{C}$. The results indicated that samples A-G of the products had $\%$ shrinkage ranging from $18-4.1 \%$ with corresponding bulk density of $0.57-$ $1.29 \mathrm{~g} / \mathrm{cm}^{3}$ respectively. The investigation revealed that samples of the bricks as stated above had crushing strength ranging from 0.008-16.05 $\mathrm{MPa}$ with corresponding percentage porosity ranging from $85.71-19.75 \%$ respectively. The estimated refractoriness using shuen's formula revealed that samples A-G had 1004.6-1506. $8^{\circ} \mathrm{C}$ range of refractoriness while the result of the refractoriness using Pyrometric Cone Equivalent (PCE) indicated that samples A-G had cone $05 \mathrm{~A}\left(1010^{\circ} \mathrm{C}\right)$ - cone $19\left(1520^{\circ} \mathrm{C}\right)$ range of refractoriness. Spalling count test result revealed that samples A-G of bricks as stated above had number of cycles ranging from 31-8 respectively. It was discovered that the higher the combustible materials the higher the shrinkage, porosity and spalling count cycles while the lower the bulk density and crushing strength of the bricks. Samples of the insulating bricks produced with rice husk gave the most favourable result when considered against the properties stated above. Therefore, 30 and 25\% (samples C and D) of the rice husk can be used as combustible material for mass production of insulating bricks.

Keywords: Insulating Brick, Pore Formers, Refractory, Refractoriness

\section{Introduction}

Refractories are ceramic materials that can withstand high temperature without appreciable deformation under service conditions. Mbah (2011; Ossai, 2005) referred to refractories as ceramic materials that have the ability to withstand the action of very high temperature and remain unmelted and undeformed under load. Charles study
(Kumar, 2011) stated that materials that can withstand very high temperature without degrading or softening are known as refractory materials. Refractory materials include certain ceramics and super alloys and are used in heat insulation of furnaces. The main function of a refractory is to withstand and maintain high temperatures and resist the abrasive and corrosive action of molten metal, slag and gases. 
The term refractory literally means "able to withstand not only heat but in many cases chemical attack, abrasion, thermal shock and rough handling" (Hloben, 2000). Refractoriness points to the resistance of extreme conditions of heat (temperature $>1000^{\circ} \mathrm{C}$ ) and corrosion when hot and molten materials are contained while being transported and/or processed. A high melting point is not the only prerequisite for a refractory material. Energy is an expensive commodity and metallurgical extraction processes tend to be very energy-demanding. An important aspect in refractory material usage is energy conservation.

According to Charles study (Kumar, 2011), refractories could be classified into two categories depending on the porosity into dense and porous refractories. Dense refractories contain porosity in the range $15-20 \%$. These refractories are used in contact with hot liquid metal and gases. On the other hand porous refractories contain porosity as high as $80 \%$. The porous refractories are light weight and possess very good thermal insulation properties. These refractories are used at high temperature or as back up lining of the furnaces. The high temperature insulation bricks are known as hot face insulation brick. The backup insulation bricks are known as cold face insulation brick. Generally, high insulating refractory brick is distinguished from lightweight material by the porosity range (45 to $75 \%$ ). Extremely lightweight materials have a porosity of 75 to $85 \%$ and ultra-lightweight, high-temperature insulating materials have porosity above $85 \%$ (Schulle and Schlegel study as cited in Jonker, 2006).

Sadik et al. (2013) opined that porous fire bricks are mainly manufactured by using such raw materials as diatomite, perlite, expanded vermiculite, calcium silicate, fire clay, kaolin, silicon carbide, quartz, alumina and lightweight refractory aggregate. Porosity is usually created by adding a combustible material to the rawmaterial mixture. During firing, the combustible material burns out and leaves a large fraction of pores within the fired body. Different types of pore formers (combustible materials) such as saw dust, foam polystyrene, fine coke, rice husk, cow dung and organic foams, or granular materials such as hallow micro sphere and bubble alumina are commonly used to produce porous bodies in insulating materials. Ugheoke et al. (2009) also stated that, over the years, insulating refractory bricks have been made in a variety of ways, such as mixing organic matter with clay and later burning it out to form pores; or a bubble structure incorporated in the clay-water mixture which is later preserved in insulating refractory brick.

The high temperature insulating refractories are used to prevent heat from moving from one place to another. Typically, a thermal insulator prevents conduction through a material and prevents heat from moving through them easily. These materials include furnaces, kilns, annealing chamber, over etc. Insulating refractory brick are lightweight, low in thermal conductivity and yet sufficiently resistant to temperature to be used successfully on the hot side of the kiln wall, thus thin walls of low thermal conductivity and low heat content (Ugheoke et al., 2009). The low heat content is particularly valuable in saving fuels and time on heating up, allows rapid changes in temperature to be made and permits rapid cooling (Caniglia and Barna, 1992). In high temperature industries, refractories play a vital role in different areas of the industrial machines. Some of the areas that desperately use refractories are the machine tool industry which uses refractories as abrasives, electrical and electronic industries as insulators, nuclear power industries as moderators in nuclear fuel, aerospace industries, ceramic industries, glass industries and iron and steel industries which consume more than $70 \%$ refractory for kiln, furnace and others (Ossai, 2005).

Otero et al. (2004) reported on the preparation of insulating refractory bricks from coal fly-ash. Due to its properties and pozzolanic activity, coal fly-ash has potential for utilization in the production of insulating bricks in combination with clays, a binder and a foaming agent (up to $50 \%$ hydrogen peroxide). The bricks obtained posses the required characteristics of mechanical resistance, porosity and thermal conductivity. Also, Vilches et al. (2003) used coal flyash and titanium waste in thermal insulation and fireproof applications which gave insulating refractory brick of standard properties. Olokode et al. (2012) investigated the suitability of cow dung to produce insulating firebrick and determined the optimal ratio of the constituent with two clay sample. The results showed that all the brick samples had good insulating characteristics, suggesting that cow dung can be used as additive in production of insulating fire-bricks. Also, production of porous firebrick from mixtures of clay and recycled refractory waste with expanded perlite addition was experimented by (Sadik et al., 2013). It was discovered that using expanded perlite as an additive to an earthenware brick to produce the pores showed that the samples maintained good characteristics of insulating refractory bricks up to $1600^{\circ} \mathrm{C}$.

Porosity is usually created by addition of combustible material to the raw material mixture of clay(s) or a bubble induced material added to clay-water mixture which is later preserved in insulating refractory brick. During sintering, the combustible material burns out and leaves a large fraction of pores within the sintered body. Various types of pore-inducers such as lignite abrasion, sawdust, styropor balls, foam polystyrene, petroleum coke, binders and organic foams, or granular materials like hollow micro spheres and bubble alumina are usually used in achieving porous bodies in the insulating material (Sutcu and Akkurt, 2009). Insulating materials that have a highly porous structure (45 to $90 \%$ porosity) 
posses low thermal conductivity values (Banerjee, 2004). The thermal conductivity not only depends on their total porosity, but it is also depends on their pore size and shape with chemical and mineralogical composition of the body (Wu et al., 2013).

Also, porous ceramics are nowadays being investigated for different applications such as bioreactors, catalyst carriers, electrodes, light-weight structural components, molten metal and hot gas filters, radiant burners, sensors and as porous implant in the area of biomaterials because of their specific useful properties such as high surface area, temperature stability, permeability, low weight and low thermal conductivity (Deheria, 2014). Investigation of any porous materials as to do with the area(s) of application(s) and the specific property(s) required.

In Nigeria today, the high temperature operating industries imports the refractory bricks for both construction and maintenance of furnaces and kilns and this has effect on foreign exchange. Also production of insulating refractory bricks has been going on with different combustible materials without establishing the best and the right proportion that must be used for production of insulating bricks that will meet up with international standards.

The growing need of insulating refractory bricks in cement, ceramic, glass, steel and some other high temperature operating or chemical processing industries have promoted investigation into various alternative uses of more economical materials (waste products). Even though there are specially made for high heat environment, insulating refractory bricks will definitely start to fail and breakdown over time, thereby needs periodical removal and replacement with new ones (Odewale et al., 2018). In this research, reliance on local materials will be a major consideration with the mind set to reduce the cost of production and furthermore reduce or eradicate importation of insulating refractory bricks.

\section{Materials and Methods}

\section{Collection of Raw Materials}

The Fire clay and Ekebedi clay used were sourced from coal mine Iva valley in Enugu State and Ekebede in Ikwuano-Oboro L.G.A. of Abia State respectively. The combustible materials were collected from the following locations: Paper pulp from Akanu Ibiam Federal Polytechnic Unwana, Saw dust from timber shade in Afikpo, Rice husk from Rice mill at Eke Market Area in Afikpo and Cow dung was source from Abattoir (slaughter house) in Eke Market Area of Afikpo in Afikpo North L.G.A of Ebonyi State all in Nigeria.

\section{Chemical Analysis of the Materials}

A chemical analysis of Enugu fire clay and Ekebedi clay were carried out to determine the percentage oxide composition of the samples. The oxides include: $\mathrm{SiO}_{2}$,
$\mathrm{Al}_{2} \mathrm{O}_{3}, \mathrm{Fe}_{2} \mathrm{O}_{3}, \mathrm{TiO}_{2}, \mathrm{CaO}, \mathrm{MgO}, \mathrm{Na}_{2} \mathrm{O}, \mathrm{K}_{3} \mathrm{O}$ and loss on ignition. The oxides were determined using buck model 210 VGP Atomic Absorption Spectrophotometer (AAS) at PRODA Enugu.

\section{Experimental Details}

\section{Preparation of Raw Materials}

\section{Drying and Calcining}

The clays and combustible materials were subjected to proper drying in an open air for seven days. The dried Enugu fire clay was sintered in the kiln at $1000^{\circ} \mathrm{C}$ whereby the clay loses its water of plasticity (Calcine Process of Enugu fire Clay) and became less plastic (grog). The clays used were crushed using jaw crusher and graded with sieve. Each of the combustible materials were crushed and ground which later graded with the aid of jaw crusher, edge mill and sieve respectively.

\section{Weighing of the Raw Materials}

The raw materials used for the production were weighed accurately using a chemical weighing balance Metra TL 3000 model. The percentage of the clays and combustible materials were weighed accurately as stipulated in the tables of composition below (Table 1).

\section{Procedure for Brick Production}

The sample ' $A$ ' percentage of the first batch was weighed and mixed thoroughly before addition of water $(18-22 \%)$. Proper mixing of the batch was observed and allowed to aged for $24 \mathrm{~h}$. The clay composite with required moisture content was uniaxially compacted using hydraulic press under a pressure of $30 \mathrm{MPa}$ into the mould. The brick was released (demould) from the mould after two (2) minutes of proper compression. This process was repeated for the remaining samples.

The pressed specimens were left to dry in open air for two (2) weeks on the floor after demoulding. During this period, the bricks were turned repeatedly to give room for even drying. The bricks were loaded into dryer (oven) at temperature of $\pm 110^{\circ} \mathrm{C}$ for period of one week for proper drying.

Dried specimens were sintered in an electric kiln. The kiln was gradually heated at the early stage of sintering to give room for burn off of carbon and combustible materials from the bricks and the damper with spy hole were left open. The damper and spy hole were closed at $850^{\circ} \mathrm{C}$ and the bricks were sintered at $1300^{\circ} \mathrm{C}$. Technological parameters values were measured after sintering steps.

Determination of Technological Properties of the Bricks

\section{Determination of Linear Shrinkage}

Seven pieces from each sample were given mark (line) with sharp object measured $10 \mathrm{~cm}$ length at the 
center point of the top side of the bricks at wet stage. The changes in length of the marks (line) were determined after drying and sintering to give linear drying shrinkage, firing shrinkage and total shrinkage of the bricks:

$$
\begin{aligned}
& \text { \% Drying shrinkage }=\frac{W L(\mathrm{~cm})-D L(\mathrm{~cm})}{W L(\mathrm{~cm})} \times 100 \\
& \% \text { Firing shrinkage }=\frac{D L(\mathrm{~cm})-F L(\mathrm{~cm})}{D L(\mathrm{~cm})} \times 100 \\
& \% \text { Total shrinkage }=\frac{W L(\mathrm{~cm})-F L(\mathrm{~cm})}{W L(\mathrm{~cm})} \times 100
\end{aligned}
$$

Where:

$D L=$ Dry length

$W L=$ Wet length and

$F L=$ Fired length

\section{Determination of Bulk Density}

The length, breadth and height of the bricks were measured and recorded in $\mathrm{cm}$. Chemical balance was used to weigh each sample to the nearest gram. The results obtained were used to first calculate the bricks' bulk volume and consequently the bulk density and the result were expressed in $\mathrm{g} / \mathrm{cm}^{3}$ :

$$
\begin{aligned}
\text { Bulk Volume of Brick } & =(L \times B \times H) \mathrm{cm}^{3} \\
& =L B H \mathrm{~cm}^{3}
\end{aligned}
$$

Let weight of Bulk $($ Brick $)=W g$

Therefore, Bulk Density $=\frac{W}{\mathrm{LBH} \mathrm{g} / \mathrm{cm}^{3}}$

\section{Determination of Porosity}

Three pieces from each samples were weighed accurately and immersed in boiling water in a large pot and boiled for $4 \mathrm{~h}$. During the boiling process, the water level was maintained by adding more water if the water level is not covering the bricks again. The bricks were left to cool for $12 \mathrm{~h}$. They were removed from the water, clean with a dry towel and weigh immediately. The differences in weight between the boiled and unboiled bricks were recorded as water porosity. This was expressed as percentage of the original weight:

$$
\% \text { porosity }=\frac{W W \text { of sample }-D W \text { of sample }}{\text { Volume of sample }} \times \frac{100}{1}
$$

Where:

$W W=$ Wet weight and

$D W=$ Dry weight

\section{Determination of Compressive Strength}

Three pieces from each samples were crushed using compressive strength tester (Buehler hydraulic press). The load (force) applied before the bricks fractured were recorded. Samples were mounted in turn on the compressive strength tester and load was applied axially at a uniform rate by operating the pump handle in an up and down movement till it failed. Compressive strength in Mpa was taken as the maximum pressure shown by the gauge dial which were read off from the machine tester (Buehler hydraulic press):

Crushing Pressure $($ Stress $)=F / A$

Where:

$$
\begin{array}{ll}
A & =\text { Area of Cuboid } \\
\text { Area of Cuboid } & =2(L B+B H+L H) M^{2} \\
F & =\text { Gauge reading calibrated in } \\
& \text { Newton (FORCE) }
\end{array}
$$

\section{Determination of Refractoriness}

The refractoriness of the bricks were estimated using Shuen's formula (Odo et al., 2009):

$$
K=\frac{360+\mathrm{Al}_{2} \mathrm{O}_{3}-R O}{0 \cdot 228}
$$

Where:

$K=$ Refractoriness $\left({ }^{\circ} \mathrm{C}\right)$

$\mathrm{Al}_{2} \mathrm{O}_{3}=$ Alumina Content in the clay

$R O=$ Sum of all the oxides beside $\mathrm{SiO}_{2}$ in the clay (or materials)

360 and 0.228 are constants

\section{Pyrometric Cone Equivalent (PCE)}

Three pieces of fired brick from each samples were shaped to the shape of standard cone sized (blunt- tipped, skew triangular pyramids with sharp edges) marked test cones. The samples were stacked in the kiln with standard cones marked reference cones. They were heated in the kiln at $2.5^{\circ} \mathrm{C} / \mathrm{Min}$ alongside reference cones. The heating process was properly monitored using the estimated result from Shuen's formula, when the test cone collapses, the Pyrometric Cone Equivalent (PCE) is given by the number of standard cone which behaves in the closest manner. The behaviour of the testing material (test cones) were compared with that of reference cones. The Pyrometric Cone Equivalent (PCE) values were based on a defined standard time - temperature relationship and the same heating rate was used throughout because different hesting rates will result in different Pyrometric Cone Equivalent (PCE) values. 


\section{Spalling Count Cycle Test}

Besides possessing refractoriness, our insulating bricks should be able to withstand many cycles of heating and cooling without cracking or spalling. The ability to withstand thermal shocks was tested by heating standard sizes of each samples (appr. $23 \times 11.5 \times 6.5 \mathrm{~cm}$ ) brick to $900^{\circ} \mathrm{C}$ in a kiln. The hot bricks were then picked out of the kiln and plunge into water of room temperature one after the other. This process was repeated until half of the brick measured by weight has cracked away due to the shock treatment. If the brick can endure 10 cycles of such heating and cooling it is very satisfactory (BIS, 2010)

\section{Results and Discussion}

\section{Result of Chemical Analysis}

\section{Discussion}

The results of chemical analysis of Enugu fire clay and Ekebedi clay shows that Enugu fire clay had 26.20\% $\mathrm{Al}_{2} \mathrm{O}_{3}$ content which falls within the range value of 25$45 \% \quad \mathrm{Al}_{2} \mathrm{O}_{3}$ content for fire clay refractories as recommended by Chesti study (Jack et al., 2013). It was indicated that Ekebedi clay had 28.03\% $\mathrm{Al}_{2} \mathrm{O}_{3}$ content Table 2 which is within the acceptable range (25-44\%) for refractory production as stated by Eke (2009; Ossai, 2005). The higher the alumina contents in clay the higher the refractoriness. It was indicated that the clays contains $\mathrm{SiO}_{2}$ content of $65.20 \%$ and $58.53 \%$ respectively, this revealed that $\mathrm{SiO}_{2}$ content of the clays are within the recommended minimum value of $40 \%$ and above for clay(s) useful for refractory and porcelain insulator's production as reported by Eke (2009; Ossai, 2005).

The clays were used together with four different combustible materials (paper pulp, saw dust, Rice husk and cow dung) to compose seven samples (A-G) of insulating bricks each from all the combustible materials in the following proportions: 40, 35, 30, 25, 20,15 and $10 \%$ Table 1.

The properties of the bricks produced investigated after sintering at $1300^{\circ} \mathrm{C}$ indicated that samples (A-G) of bricks with paper pulp had percentage linear shrinkage ranging from $13.1-4.1 \%$, samples with saw dust had range of $11.5-7.8 \%$, samples with rice husk had range of 10.4-5.2\%, while that of samples with cow dung had range of $18-5.8 \%$ Fig. 1. This is may occur as a result of the expansion that accompanied the low quartz to high quartz and the high quartz to high critobalite polymorphic transformations that took place during sintering at 573 and $1300^{\circ} \mathrm{C}$. The more the insulating brick shrinks, the less porous it is, hence the denser it becomes (Odo et al., 2009). Also, shrinkage may be due to the percentage of combustible material (burn out) added to create pores in the bricks. The higher the \% combustible material the higher the \% linear shrinkage as it is clearly shown in the Fig. 1. It is clearly indicated in Fig. 1 that at $40 \%$ of combustible materials, the cow dung (sample A) had highest \% linear shrinkage (18\%), followed by paper pulp (sample A) $(13.1 \%$ ) while rice hush (sample A) had the lowest $(10.4 \%)$ at the point. The increase in $\%$ linear shrinkage with increasing \% combustible materials as shown in Fig. 1 is because the combustible material which occupied spaces in the clay body burnt off on sintering and thereby leaving open space which gave room for shrinkage to occur. The result of the shrinkage of most of the samples fell out of the recommended value range of $7-10 \%$ for refractories as reported by Chester study (Chukwudi and Eng, 2008), Misra study (Jack et al., 2013; Eke, 2009) except that of samples C and D of paper pulp, C-G of saw dust, B-D of Rice husk and $\mathrm{E}$ and $\mathrm{F}$ of cow dung bricks that fell within the recommended range.

The result of the bulk density shows that the samples with paper pulp (A-G) had bulk density ranging from $1.06-1.67 \mathrm{~g} / \mathrm{cm}^{3}$, samples with saw dust had range of $0.57-0.81 \mathrm{~g} / \mathrm{cm}^{3}$, samples with rice husk had range of $0.64-1.29 \mathrm{~g} / \mathrm{cm}^{3}$ and that samples of cow dung had range of $0.60-0.81 \mathrm{~g} / \mathrm{cm}^{3} \mathrm{Fig}$. 2. The required bulk density of insulating bricks usually low (0.8-1.0 $\mathrm{g} / \mathrm{cm}^{3}$ ) due to the pores in the bricks (Caniglia and Barna, 1992). It was noticed in Fig. 2 that the higher the percentage of combustible materials, the lower the bulk density. The decrease in the bulk density with increasing $\%$ combustible materials could be explained with the fact that the combustible materials burnt off on sintering thereby making the samples to lose weight. At $10 \%$ percentage combustible materials, paper pulp (sample G) had the highest bulk density $\left(1.67 \mathrm{~g} / \mathrm{cm}^{3}\right)$ while saw dust and cow dung (sample G) had $\left(0.81 \mathrm{~g} / \mathrm{cm}^{3}\right)$ the lowest Fig. 2. Only insulating refractory bricks produced with paper pulp (A-G), samples $G$ of saw dust and cow dung with samples C-E of Rice husk fell within the recommended range, others fell below it (i.e., 0.8-1.0 $\mathrm{g} / \mathrm{cm}^{3}$ ) (Charles study, as cited in Kumar, 2011).

The result of the crushing strength of the bricks revealed that samples A- G of bricks with paper pulp had crushing strength ranging from 2.86-16.05 MPa, samples with saw dust had range of $0.008-0.085 \mathrm{MPa}$, samples with rice husk had range of $0.036-1.992 \mathrm{MPa}$, while that of cow dung had range of 0.054-1.204 MPa Fig. 3. It was discovered that the higher the percentage of combustible materials the lower the crushing strength of the insulating bricks Fig. 3. The high compressive strength value of paper pulp samples may be due to the fact that the combustible materials (paper pulp) burnt off on sintering earlier than others thereby making the 
sample(s) to lose weight and fused together which may lead to the formation of the glassy phase that brings about the bonding strength. Also, it is clearly revealed in Fig. 1 that paper pulp samples had relatively low shrinkage and highest bulk density in Fig. 2 with lowest porosity in Fig. 4 which definitely led to highest compressive strength value of paper pulp samples as shown in Fig. 3. The more the insulating refractory brick shrinks, the less porous it is, then the denser it becomes. Also, higher porosity implies less load bearing capacity and weak samples. Therefore, the flexural strength decreases with higher combustible materials. Only samples $\mathrm{C}$ to $\mathrm{G}$ of paper pulp bricks fell within the required range, others fell below the recommended ranges i.e., minimum of $5 \mathrm{MPa}$ (Chukwudi and Eng, 2008; Ossai, 2005).

Table 1: Insulating brick body composition

\begin{tabular}{llll}
\hline Samples & Enugu fire clay $(\%)$ & Ekebedi clay $(\%)$ & Combustible material $(\%)$ \\
\hline A & 55 & 5 & 40 \\
B & 60 & 5 & 35 \\
C & 65 & 5 & 30 \\
D & 70 & 5 & 25 \\
E & 75 & 5 & 20 \\
F & 80 & 5 & 15 \\
G & 85 & 5 & 10 \\
\hline
\end{tabular}

Note: The combustible materials used are Paper pulp, Saw dust, Rice husk and Cow dung

Table 2: The result of chemical analysis of the Enugu fire clay and Ekebedi clay

\begin{tabular}{|c|c|c|}
\hline Parameters & Enugu fire clay $\%$ chemical composition & Ekebedi clay $\%$ chemical composition \\
\hline$\overline{\mathrm{SiO}_{2}}$ & 65.20 & 58.53 \\
\hline $\mathrm{Al}_{2} \mathrm{O}_{3}$ & 26.20 & 28.03 \\
\hline $\mathrm{Fe}_{2} \mathrm{O}_{3}$ & 3.42 & 1.41 \\
\hline $\mathrm{TiO}_{2}$ & 0.14 & 1.12 \\
\hline $\mathrm{CaO}$ & 0.13 & 0.28 \\
\hline $\mathrm{MgO}$ & 0.17 & 0.08 \\
\hline $\mathrm{Na}_{2} \mathrm{O}$ & 0.25 & 0.03 \\
\hline $\mathrm{K}_{2} \mathrm{O}$ & 0.26 & 0.033 \\
\hline L.O.I & 4.09 & 8.0 \\
\hline Other oxides/impurities & 0.14 & 2.19 \\
\hline
\end{tabular}

NOTE: Combustible materials (paper pulp, saw dust, rice hush and cow dung) are stated at legend with different colours of lines indicting them in the graphs

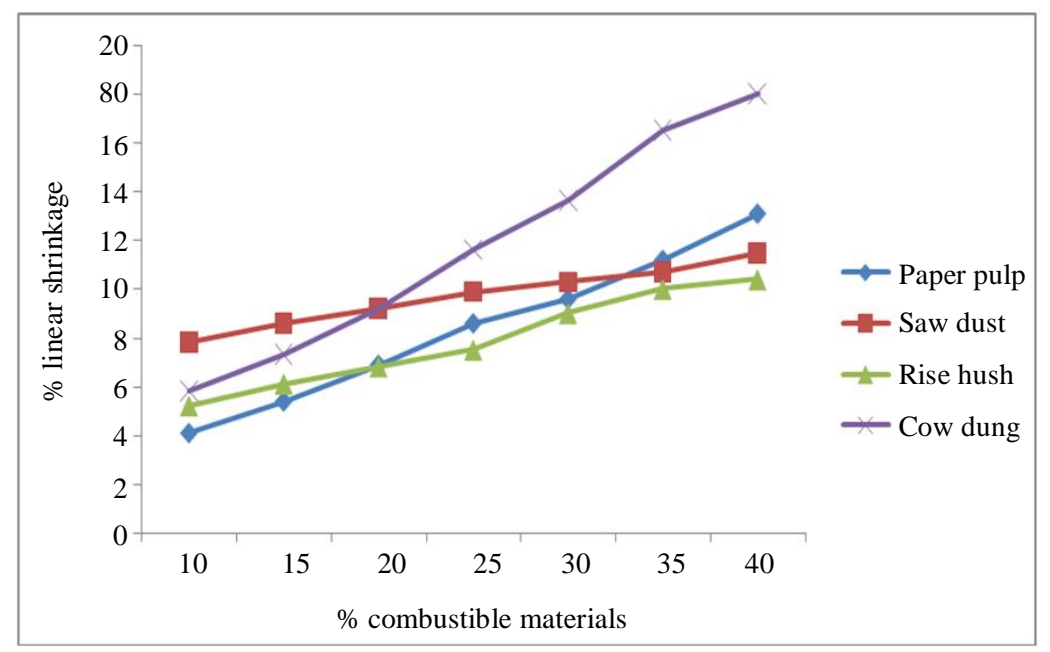

Fig. 1: Effects of \% composition of combustibles on shrinkage of firebricks 


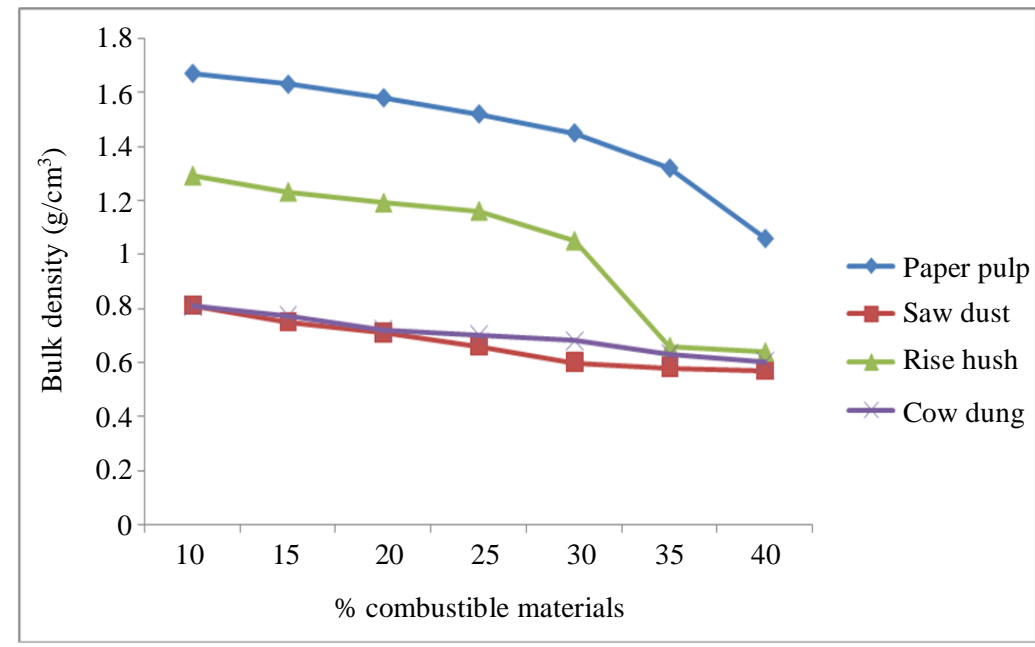

Fig. 2: Effects of \% composition of combustibles on bulk density of firebricks

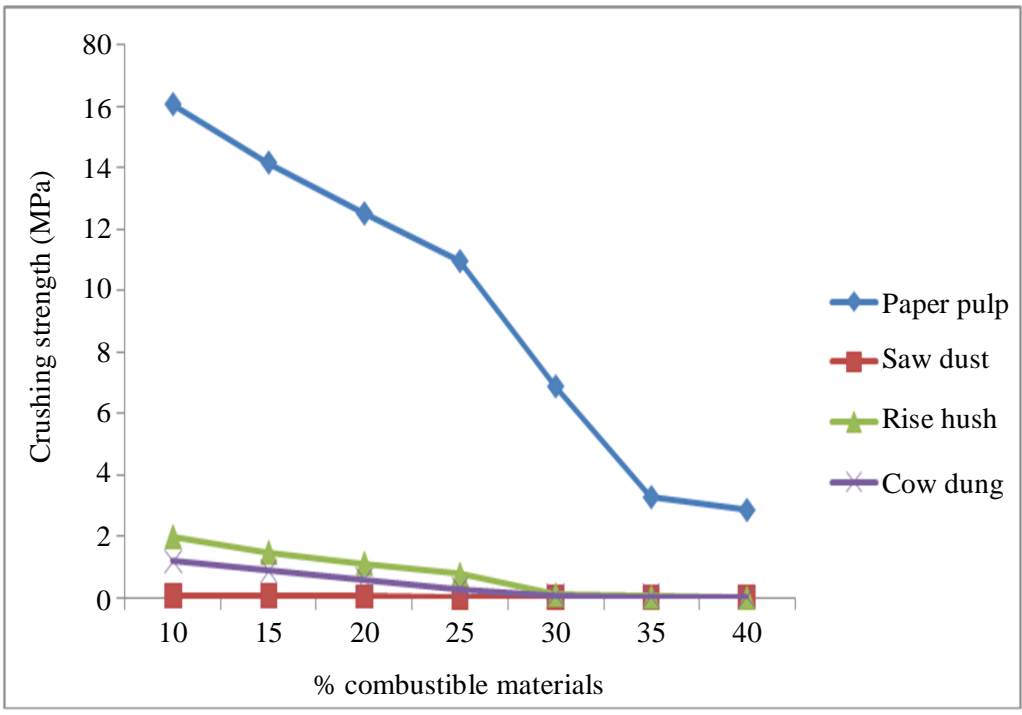

Fig. 3: Effects of \% composition of combustibles on crushing strength of firebricks

The result of the percentage porosity of the bricks indicated that samples A-G of bricks with paper pulp had percentage porosity ranging $38.75-19.75 \%$, samples with saw dust had range of 84.34-37.98\% and samples with rice husk had range of $86.63-36.37 \%$ while samples with cow dung had range of $85.71-47.11 \%$ Fig. 4. This shows that porosity can be induced in a body by addition of organic or combustible material to the based clay. The clay acts as a bond and the combustible material gives the cellurity. The more the combustible material, the more the cellurity created and the higher the porosity as shown in Fig. 4. It was discovered that the higher the percentage of combustible materials the higher the burn out and created pores, the higher the porosity of the bricks. At $40 \%$ of combustible materials, Cow dung sample had the highest \% porosity $(85.71 \%)$ while paper pulp had the lowest $(38.75 \%)$ as indicated in Fig. 4. However, all samples made with paper pulp and samples $\mathrm{G}$ of saw dust and rice husk fell below the required recommended porosity of an insulating refractory bricks. While the remaining samples fell within the required range of $40-85 \%$ porosity as stated by Charles study (Kumar, 2011) and Schulle and Schlegel study (Jonker, 2006).

The values of density and porosity determined by standard methods are used to recommend or predict the use of refractories for specific uses. In general, the higher the density, the lower the porosity. Also, other physical properties, such as strength, abrasion and gas permeability, are often related to the density and porosity of the refractory. Compressive Strengths (Cold and hot) are 
importance. The physical strengths, in both cold and hot conditions are often characterized as measures of the use of a refractory. The cold compressive strength of a refractory material is an indication of its suitability for use of refractories in construction (handling and installation). It is a combined measure of the refractory for the strength of the grains and also of the bonding system, whereas hot strengths indicate how the refractory will perform when used at elevated temperatures (Eke, 2009).

The estimated refractoriness result using shuen's formula indicated that samples A-G of all the bricks had refractoriness of A- $1004.6^{\circ} \mathrm{C}, \mathrm{B}-1088.3^{\circ} \mathrm{C}, \mathrm{C}-1172.7^{\circ} \mathrm{C}$, D- $1255.7^{\circ} \mathrm{C}, \mathrm{E}-1339.4^{\circ} \mathrm{C}, \mathrm{F}-1423.1^{\circ} \mathrm{C}$ and G- $1506.8^{\circ} \mathrm{C}$ Fig. 5. The relatively high refractoriness can be attributed reasonably due to high alumina content of the clays and low amount of impurity oxides as their presence in high amount usually have an adverse effect on the refractoriness (Table 2). The increase in the percentages of Enugu fire clay i.e. decreases in \% Combustible materials led to increase in refractoriness as indicated in Fig. 5. Sample G of the insulating bricks had the highest refractoriness $\left(1506.8^{\circ} \mathrm{C}\right)$ while sample $\mathrm{A}$ had the lowest $\left(1004.6^{\circ} \mathrm{C}\right)$ as shown in Fig. 5. All the bricks met the required refractoriness for insulating refractory bricks i.e., minimum of $1000^{\circ} \mathrm{C}$ (Jonker, 2006).

The result of the refractoriness using Pyrometric Cone Equivalent (PCE) test investigated shows that samples A-G of all the bricks had refractoriness of Acone $05 \mathrm{~A}\left(1010^{\circ} \mathrm{C}\right), \mathrm{B}$ - cone $01 \mathrm{~A}\left(1090^{\circ} \mathrm{C}\right), \mathrm{C}-$ cone 5 $\left(1180^{\circ} \mathrm{C}\right), \mathrm{D}$-cone $8 \mathrm{~A}\left(1260^{\circ} \mathrm{C}\right), \mathrm{E}-$ cone $12\left(1350^{\circ} \mathrm{C}\right), \mathrm{F}$ - cone $15\left(14350^{\circ} \mathrm{C}\right)$ and $\mathrm{G}$ - cone $19\left(1520^{\circ} \mathrm{C}\right)$ Fig. 6. This may be due to appreciation of the $\mathrm{Al}_{2} \mathrm{O}_{3}$ content and high fusing temperature of $\mathrm{SiO}_{2}$ content available in the body composition (Table 1 and 2). The refractoriness of the insulating bricks increase by 80 to $90^{\circ} \mathrm{C}$ with increase in the percentages of Enugu fire clay i.e., decreases in \% Combustible materials led to increase in the refractoriness as indicated in Fig. 6. This may be attributed to higher alumina content $(26.20 \%)$ of Enugu fire clay (Table 1 and 2). It is a well known fact that temperature rises as alumina content increases. Sample G (with $85 \%$ fire clay) of the insulating bricks had the highest refractoriness $\left(1520^{\circ} \mathrm{C}\right.$ ) while sample A (with $55 \%$ fire clay) had the lowest $\left(1090^{\circ} \mathrm{C}\right)$ as shown in Fig. 6 . All the bricks met the required refractoriness for insulating refractory bricks above cone $08\left(990^{\circ} \mathrm{C}\right)$ i.e., minimum of $1000^{\circ} \mathrm{C}$ (Jonker, 2006).

It was clearly indicated that refractoriness test using Pyrometric Cone Equivalent (PCE) show that the brick samples possessed better refractoriness when compared with the estimated refractoriness results from shuen's formula as indicated in Fig. 7.

The result of the Spalling count cycle investigated revealed that samples made of paper pulp (A-G) has spalling count cycles ranging from 18-8, samples with saw dust (A-G) had range of 31-21, samples with Rice husk (A-G) had range of 32-22 while that of cow dung (A-G) had range of 30-21 Fig. 8. It was well indicated in Fig. 8 that samples of paper pulp had the lowest number of spalling count cycle (18-8) while others are relatively okay. This may be due to high bulk density of paper pulp samples as shown in Fig. 2 and their low porosity as indicated in Fig. 4 which usually lead to low spalling count cycle shown in Fig. 8 (i.e., high thermal conductivity). It was revealed that the higher the porosity the higher the number of spalling count cycles (Fig. 4 to 8 ). The lower the bulk density, the lower the thermal conductivity of an insulating material. Also,linsulating materials that have a highly porous body posse's low thermal conductivity value (Banerjee, 2004). The thermal conductivity is not only depends on their total porosity, but it is also depends on their pore size and shape with chemical and mineralogical composition of the based body (Wu et al., 2013). The result shows that samples of paper pulp bricks fell below the recommended numbers of cycle while the remaining samples fell within the recommended range of 20-32 number of cycles (BIS, 2010; Chukwudi and Eng, 2008).

Most high-temperature processes experience heating and cooling. Both refractory grains and the bonding system expands while being heated and contract during cooling. Having similar grains in the structure, the thermal shock resistance depends on the matrix bonding the grains. Thus, refractories having structures with built-in micro-cracks of defects show better thermal shock resistance than with rigid systems. In some refractories, the bonding system, by nature, possesses micro-structural defects or cracks that provide better thermal shock resistance. Like most ceramic products, certain strength properties usually improve as bulk density improves. In many cases, there is a relationship between thermal conductivity and strength. Other physical properties, such as strength, abrasion and gas permeability, are often related to the density and porosity of the refractory. Also, porosity is affecting both thermal conductivity and strength. However, as density improves, spalling resistance may decline. It is best to look for combinations of properties that contribute to success, such as density and permanent linear change together.

It was discovered that the higher the combustible materials the higher the shrinkage, porosity and spalling count cycle while the lower the bulk density and crushing strength of the bricks. However, sample of bricks produced using rice husk gave the most favourable result when considering the percentage linear shrinkage, bulk density, average crushing strength, moderate refractoriness and standard spalling count cycle. Therefore, 30 and 25\% (samples C and D) of Rice husk can be used as combustible material for mass production of insulating bricks. 
Isiaka Olajide Odewale et al. / International Journal of Structural Glass and Advanced Materials Research 2020, 4 (1): 168.179 DOI: 10.3844/sgamrsp.2020.168.179

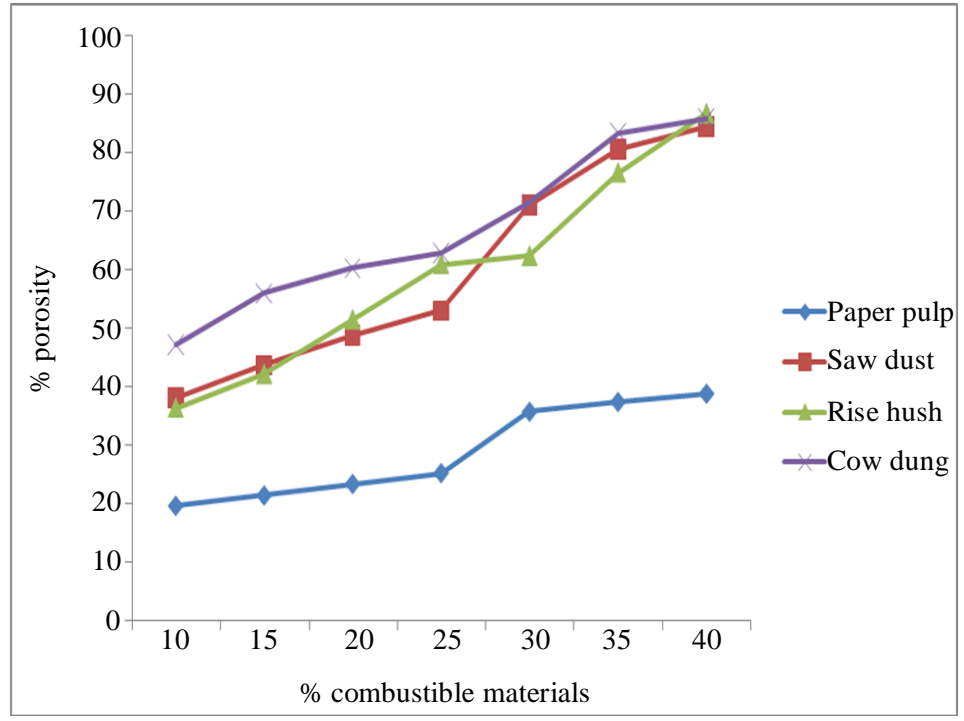

Fig. 4: Effects of \% composition of combustibles on porosity of firebricks

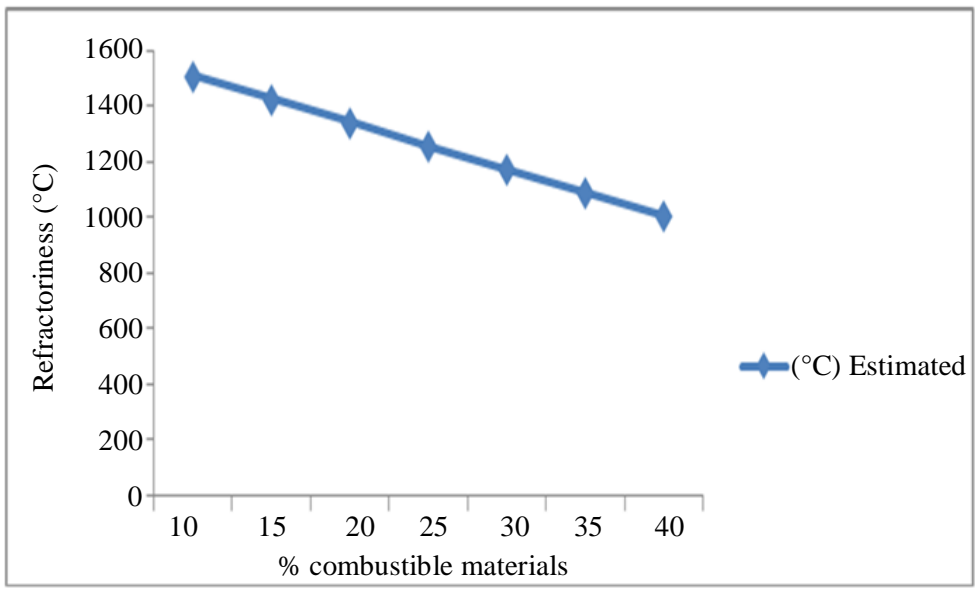

Fig. 5: Effects of \% composition of combustibles on estimated refractoriness using shuen's formula of firebricks

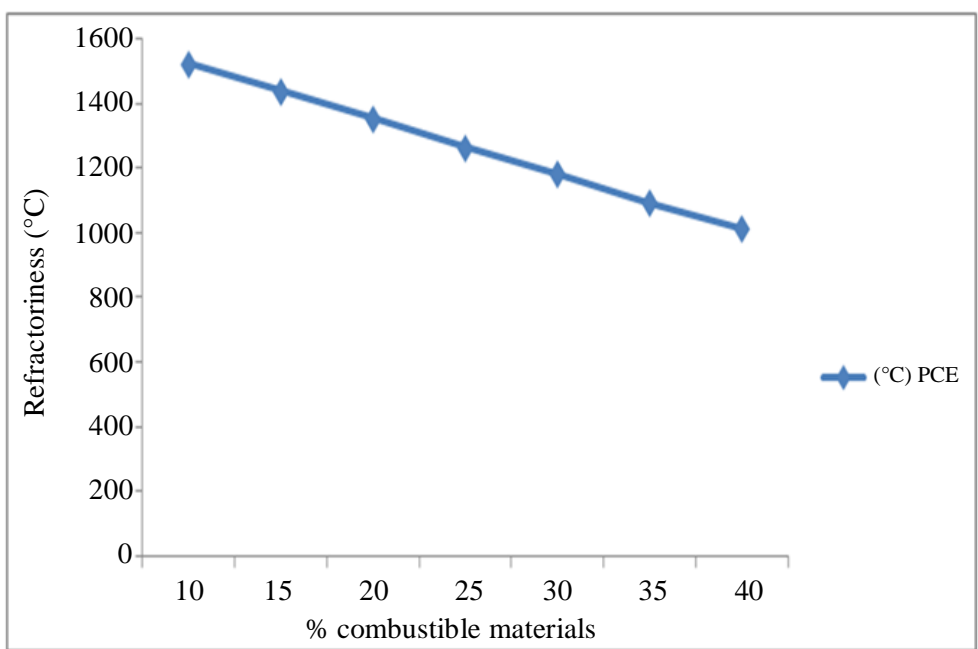

Fig. 6: Effects of \% composition of combustibles on refractoriness using pyrometric cone equivalent of firebricks 


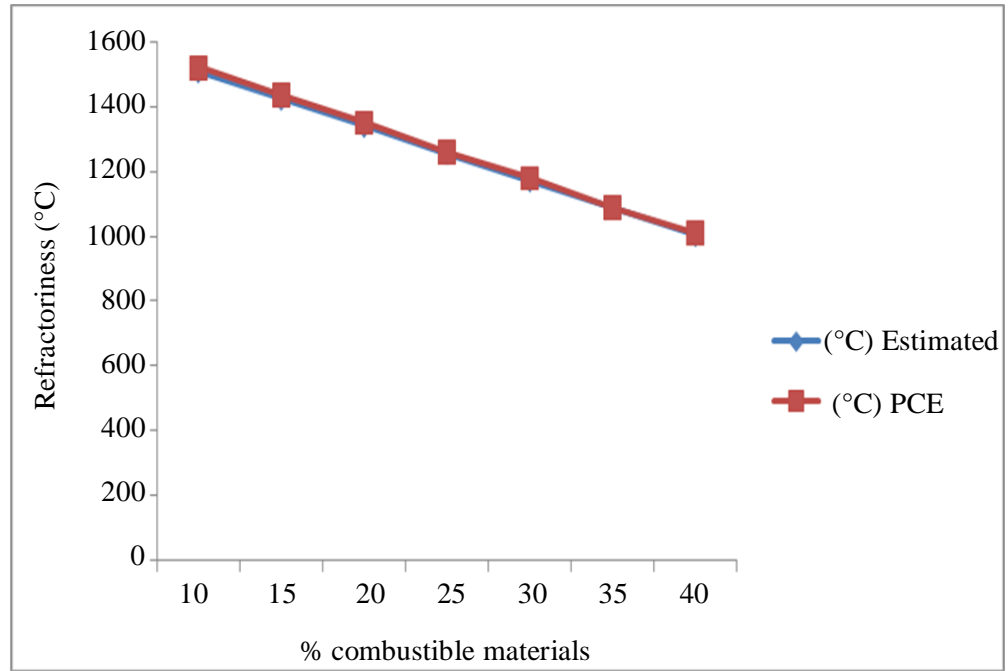

Fig. 7: Effects of \% composition of combustibles on estimated refractoriness using shuen's formular and pyrometric cone equivalent of firebricks

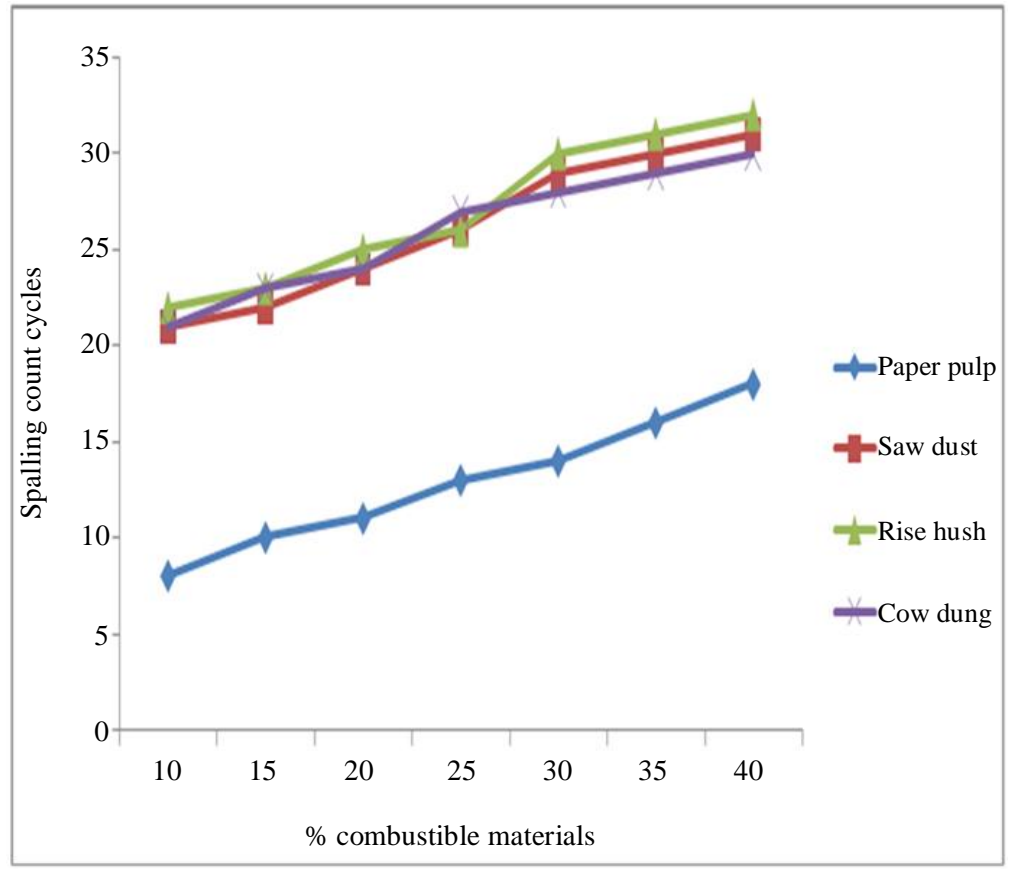

Fig. 8: Effects of \% composition of combustibles on spalling count cycles of firebricks

\section{Conclusion}

It was discovered that the higher the combustible materials the higher the shrinkage, porosity and spalling count cycle while the lower the bulk density and crushing strength of the bricks. Moreover, sample of bricks produced with rice husk gave the most favourable result when considering the result of all the properties. This revealed that good quality of insulating refractory bricks of international standard can be produced locally with $100 \%$ local content. Mass production of the insulating refractory bricks from local raw materials will not only save cost of importation of this important product, but it will also encourage industrialization and boost the economy of the country. Therefore, 30 and $25 \%$ (samples C and D) of rice husk can be used as combustible material for mass production of international standards insulating refractory bricks.

Development is continuing on the study area and the limits have not yet been reached. Production of insulating refractory bricks has been going on with different combustible materials without establishing (comparism) the 
best and the right proportion that must be used for production of insulating bricks that will meet up with international standards, therefore this paper has done that.

\section{Acknowledgement}

Thanks to the Ceramics and Glass Technology Department of Akanu Ibiam Federal Polytechnic Unwana, Ebonyi State, Nigeria, for given us the opportunity to use their facility during the research.

\section{Funding}

This research was self sponsored by authors.

\section{Author's Contributions}

Isiaka Olajide Odewale: Designed the study and contributed in writing the first draft of the manuscript.

Ebere Monica Ameh: Managed the literature searches.

Victor Tyonenge Dhave Amaakaven: Performed the statistical analysis.

Felix Uga Idu: Performed the chemical analysis.

Collins Chinecherem Aluma: Wrote the protocol.

Babatunde Joseph David: Wrote the first draft of the manuscript.

Oluwakayode. Boluwaji Abe: Designed the metal mould used.

Dele Kehinde Ogunkunle: Fabricated the metal mould used.

\section{Ethics}

This article is original and contains unpublished material. The corresponding author confirms that all of the other authors have read and approved the manuscript and no ethical issues involved with declaration of no conflict of interest.

\section{References}

Banerjee, S. (2004). Properties of Refractories in Refractories Handbook. Edited by Charles A. Schacht. Schacht Consulting Services Pittsburgh, Pennsylvania, USA.

BIS, (2010). Methods of sampling and physical tests for refractory materials, Part 3: Determination of spalling resistance. Bureau of Indian Standards.

Caniglia, S., \& Barna, G. L. (1992). Handbook of industrial refractories technology: principles, types, properties and applications. William Andrew.

Sadik, C., Albizane, A., \& El Amrani, I. E. (2013). Production of porous firebrick from mixtures of clay and recycled refractory waste with expanded perlite addition. J. Mater. Environ. Sci, 4(6), 981-986.
Chukwudi, B. C., \& Eng, M. (2008). Characterization and evaluation of the refractory properties of Nsu clay deposit in Imo State Nigeria. Pacific Journal of Science and Technology, 9(2), 487-494.

Deheria, S. S. (2014). Production of alumina based porous ceramics using graphite powder as the pore former (Doctoral dissertation).

Eke, H. O, (2009). Introduction to ceramic technology. Aku Graphic Press Aba Nigeria, 20, 47-51.

Hloben, P. (2000). Refractory materials: Major industrial applications. Rexxon.

Jock, A. A., Ayeni, F. A., Jongs, L. S., \& Kangpe, N. S. (2013). Development of Refractory Bricks from Nigerian NAFUTA clay deposit. International journal of materials, methods and technologies, 1(10), 189-195.

Jonker, A. (2006). Insulating refractory materials from inorganic waste resources.

Kumar, R. (2011). Development of Low Bulk Density Fireclay Insulation Brick (Doctoral dissertation).

Mbah, A. C, (2011). Fundamentals of Materials Science. Wiley, C. City and Company Ltd Enugu, Nigeria, pp, 936.

Odewale, I. O., Ameh, E. M., \& Amaakaven, V. T. D. (2018). Comparative analysis of insulating brick produced from locally sourced clays and combustible materials.

Odo, J. U., Nwajagu, C. O., \& Nnuka, E. E. (2009). Characterization of ezebunagu clay deposit and its potential for industrial applications. Journal Metallurgy and Materials Engineering, 4(2), 31-37.

Olokode, O. S., Aiyedun, P. O., Raheem, D. M., Owoeyeè, F. T., \& Anyanwu, B. U. (2012). Production and characterization of clay-cow dung insulating fire-bricks. Global Advanced Research Journal of Engineering, Technology and Innovation, 1(7), 162-167.

Ossai, A. A. (2005). Introduction to alumino-silicate and other refractories. Olicon Publication Enugu, Nigeria, 17, 25-28.

Otero, J. G., Blanco, F., Garcia, M. P., \& Ayala, J. (2004). Manufacture of refractory insulating bricks using fly ash and clay. British ceramic transactions, 103(4), 181-186.

Sutcu, M., \& Akkurt, S. (2009). The use of recycled paper processing residues in making porous brick with reduced thermal conductivity. Ceramics international, 35(7), 2625-2631.

Ugheoke, B. I., Onche, E. O., Namessan, O. N., \& Asikpo, G. A. (2006). Property optimization of kaolin-rice husk insulating fire-bricks. Leonardo Electronic Journal of Practices and Technologies, 9, $167-178$ 
Isiaka Olajide Odewale et al. / International Journal of Structural Glass and Advanced Materials Research 2020, 4 (1): 168.179 DOI: 10.3844/sgamrsp.2020.168.179

Vilches, L. F., Fernández-Pereira, C., del Valle, J. O., \& Vale, J. (2003). Recycling potential of coal fly ash and titanium waste as new fireproof products. Chemical Engineering Journal, 95(1-3), 155-161.
Wu, X., Ma, H. Chen, X. Li Z. and Li, J. (2013). Production of porous and light -weight bricks with acceptable flexural strength. New Journal Glass. Ceram., 3, 43-43. 